\section{Seguir, seguir. Hacer lo siguiente}

\author{
Lamosa-Laboratorio Artístico Modulable (Cuenca)
}

Del 12 de noviembre de 2019 al 22 de enero de 2020

\section{Sobrevivir}

La exposición de Irati Inoriza y Abel Jaramillo Seguir, seguir. Hacer lo siguiente tiene como motivo principal la supervivencia. La supervivencia del cuerpo, la supervivencia de las imágenes. Dos horizontes de una misma inquietud que los artistas abordan conjuntamente poniendo a dialogar sus piezas tanto entre ellas como con el espacio expositivo, siendo la mayoría "fragmentos» de proyectos anteriores, lo cual acentúa el carácter ecléctico, procesual, informal de la propuesta.

La obra de Irari Inoriza (Bilbao, 1992), situada «entre el ensayo visual y la construcción de ecosistemas artísticos", como ella manifiesta, es eminentemente contextual, trabajando a partir de proyectos para espacios específicos que propicien situaciones de "contacto" entre los espectadores empleando las tecnologías de la imagen. El cuerpo es central en sus trabajos, por eso aquí la pregunta acerca de su supervivencia. Pensemos, a propósito, en la obsesión del Occidente desarrollado por el culto al cuerpo: en su afán productivista, propugna un ideal de eterna juventud con la dispensa diaria de productos que mejoran nuestra estética y aptitudes físicas.

Por su parte, Abel Jaramillo (Badajoz, 1993) trabaja con la historia para visibilizar los relatos velados de los discursos hegemónicos a partir de una experiencia inmersiva e interactiva, pero de un modo más austero y poético, dando especial protagonismo a la palabra. Cuestiona para esta exhibición los límites de la obra centrándose, como comenta, en «la supervivencia de las imágenes». Por tanto, presupone a la imagen una cierta activación, un viaje continuo ejercido en su constante compartir, al igual que la obra de arte. En un momento de proliferación y profusión masiva a través de los medios de comunicación, ¿cómo el artista, en tanto productor simbólico, se sitúa ante tal vorágine?

\section{Soportar}

Si cuerpo e imagen están inevitablemente unidos, la obra de nuestros artistas configura un todo sin catalogaciones o esci-
1. Vista de Irati Inoriza, Connecting (2018) y Abel Jaramillo, Sin título (2019)

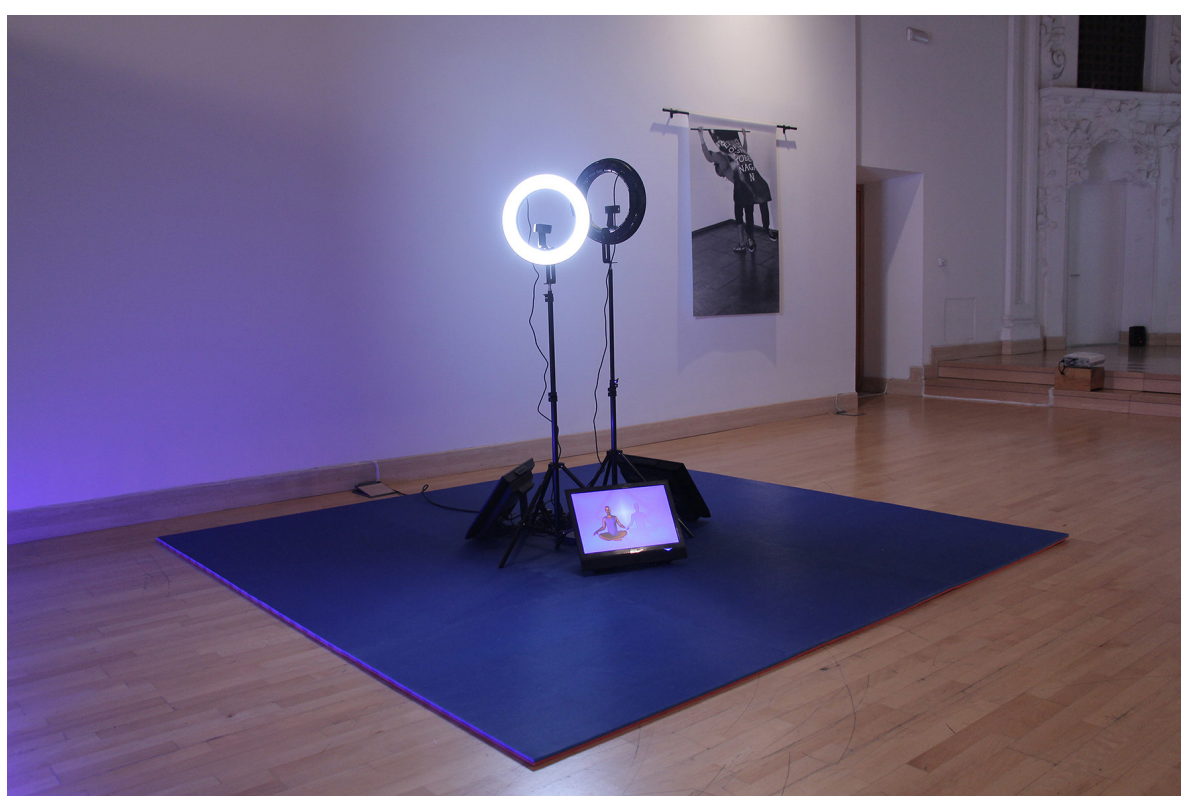


siones identitarias previas (no hay cartelas). En el centro de la sala encontramos la instalación performativa de Inoriza Connecting (2018). Sobre un tatami de color azul ha instalado tres pantallas junto a dos focos de luz de anillo sobre trípode. Estos se emplean popularmente para suavizar las imperfecciones de los rostros de los youtuber y tienen una plataforma para colocar el Smartphone, desde donde grabar el vídeo. Invita así a iniciar un directo en el momento en que el espectador se sitúa frente a la pantalla. La figura virtual de la pantalla, una animación en 3D de un cuerpo sin género, también de color azul, nos propone una serie de ejercicios de reiki y bio-danza. Los espectadores son tentados así a dialogar con esas instrucciones acerca de cómo respirar, moverse y relacionarse con la comunidad efímera que se genera (los compañeros de al lado que se hayan unido al ejercicio).

Si bien el tatami nos soporta y propicia la creación de un vínculo (también la comodidad, al invitar a descalzarnos), sobre la pared de la izquierda de la instalación encontramos otra metáfora del soportar -soportar la imagen-. Sin título (2019), de Jaramillo consiste en una impresión sobre lona pegada a una barra de hierro, cual bandera, y está basada en una performance titulada Act I: Failure is the oportunitiy to begin again para la galería Estrany de la Mota (2018-2019). Esta formaba «una especie de laboratorio de acción a partir de elementos y archivos en torno a la idea de trabajo, de seguir unas pautas y la posibilidad de alterar la historia». Estamos así ante una imagen tomada de dos de los cuerpos participantes en la performance donde levantaban una bandera con el mismo texto del título, superpuesto a la imagen de un cuadro de Sísifo. Jaramillo usa ese registro de su obra anterior, imprimiéndolo sobre el mismo material de aquella bandera -lona-, «replicando» su obra. Su referencia al mito de Sísifo -castigado por los dioses a cargar una roca eternamente- alude al trabajo, solo que ahora es otro cuerpo el que es soportado. Ambas piezas manifiestan la inevitabilidad del estar juntos a través de una instalación performativa y una performance objetualizada [1].

\section{Competir}

Tras una conversación con un historiador del arte en Atenas, Inoriza se sorprendió de un reciente hallazgo: la primera imagen artística sobre el contacto humano en el contexto occi- dental es la encontrada en una vasija de la antigua Grecia en la que dos cuerpos aparecen luchando.

Que la lucha esté en el origen de todo entrar en relación supuso el punto de partida de Zeus en Adidas (2019). Cámara en mano ella rodea la escultura griega que visitó en el Museo Arqueológico de Atenas. Al vídeo resultante luego superpone una animación digital con las líneas características de los chándal de Adidas, apuntando a la esfera de los deportes y la competitividad. El espíritu olímpico griego es llevado a la contemporaneidad en tanto símbolos de la «lucha» capitalista y corporativista (no en vano se emplea dicha firma, marca o compañía). Esta incursión surgió de su serie de dibujos de bailarinas de contact-dance de los puntos de contacto de ambos cuerpos así como del diseño de sus atuendos. La obra está en la pared de enfrente de Sin título (2019) de Jaramillo (la pared derecha), rodeando Connecting.

Zeus en Adidas es un vídeo, de formato vertical, reproducido sobre una pantalla apoyada en el suelo contra la pared y se sustenta sobre Sin título (la playa) (2016) de Abel: un conjunto de carteles que repiten la frase: «El día de mañana». Este fragmento de obra forma parte del proyecto $\mathrm{La}$ Playa, llevado al Centro Cultural Montehermoso en 2016 y versaba sobre la incertidumbre laboral, la productividad y la gestión del tiempo.

\section{Unir}

BLUE: Contact Line: RED fue el proyecto de Inoriza becado también por el Centro Cultural Montehermoso. De él extraemos dos fotografías, Cuerpo y líneas (2019), en la misma pared de Sin título (La playa), apoyada también sobre dicha obra; y Dorada (2019), que cuelga sobre la tercera pared que rodea Connecting, en la entrada de la sala. El proyecto partió de la película Tron (1982), en la que dos sociedades humanoides, una caracterizada por brillar de un intenso color rojo y la otra por su resplandeciente azul son enfrentadas en un mundo distópico por su supervivencia.

Su proyecto se basó en esta dualidad. El rojo aludiría a lo instintivo, lo físico, y el azul a lo imaginado, lo onírico. Partió de vídeos que realizó en combates de lucha libre olímpica femenina y posteriormente trabajó esas imágenes desde la animación y el dibujo. Completó el proyecto con las fotografías que encontró de personas tatuadas con líneas de ambos co- 
2.1. Vista de Irati Inoriza, Zeus en Adidas (2019) y Abel Jaramillo, Sin título (La playa) (2016) y 2.2. Vista del mismo conjunto con Irati Inoriza Cuerpo y líneas (2019) y Connecting (2018)
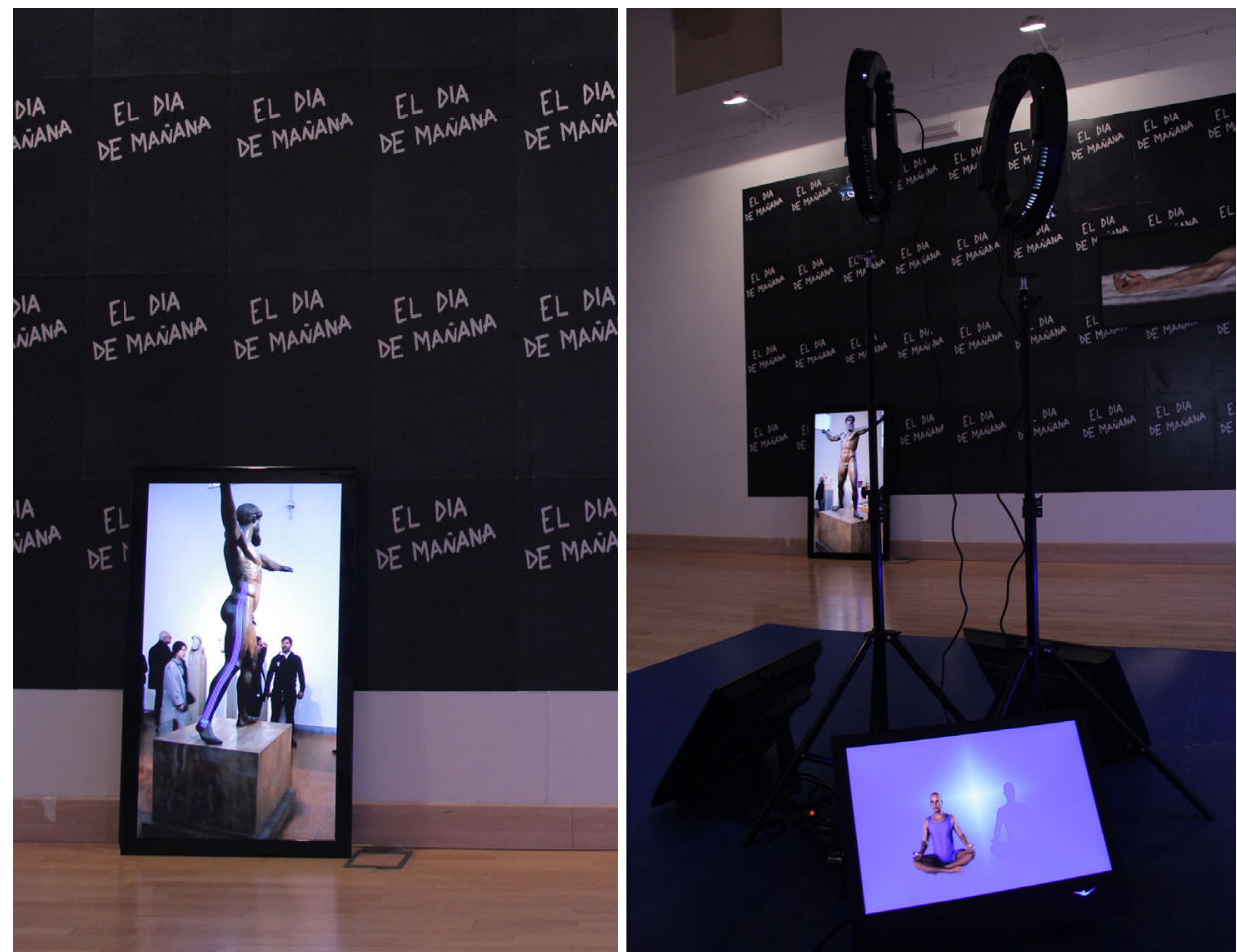

lores, y entre ellas aparecen estas dos obras, que conceptualmente muestran la parte del cuerpo que es dada en primera instancia a un desconocido: la mano. Mientras realizaba estos dibujos, encontró justamente que la pareja de un amigo suyo tenía el tatuaje de unas líneas de color rojo y azul en su antebrazo. En Cuerpo y líneas (2019) asistimos al primer plano de su brazo extendido. De casualidad, encontró en Instagram la imagen de una fiesta en Uruguay donde aparece una mano en primer plano con un tatuaje similar -en este caso venas entrelazadas- la cual sostiene un torso desnudo cubierto en purpurina, de ahí el título Dorada [2.1] y [2.2]

\section{Fracasar}

Al fondo de la sala, en el espacio del altar de la antigua capilla reformada como galería, concluimos con las dos piezas de Jaramillo, Sin título (2019) y The need to have walls (2019). La primera la forma una tabla de madera, dos gatos mecánicos, metacrilato e impresiones sobre papel. El conjunto suscita inestabilidad pues el uso del improvisado mueble a modo de mesita baja queda en suspenso. El ar- tista explora aquí qué queda al margen o es descartado y la cuestión de qué es un soporte. Sobre la madera ha impreso unas palabras extraídas de la película de Marguerite Duras El camión (1977): «Que el mundo se precipite a su pérdida es su única política». La película apunta al fracaso como recurso estético pues desafía el formato narrativo del filme a partir de los dos personajes principales, los cuales mientras viajan en un camión leen el guion de una película que no tiene lugar, dando espacio al espectador a la recreación de sus propias imágenes. Simbólicamente, estas dos herramientas de automoción sirven para elevar (de ahí la película El camión) y ver lo oculto, lo soterrado. Según Abel, este trabajo «reflexiona acerca del texto como soporte y la supervivencia de la historia», de los significados, los relatos y los fragmentos, y la impresión del suelo muestra un fotograma de un figurante de caídas: una persona cuyo trabajo es aprender a caerse.

Siguiendo esta línea, el vídeo The need to have walls (2019) relata la historia de un viaje personal deliberadamente frustrado. Jaramillo trató de llegar a una playa cercana a Lisboa, Praia Grande, para visitar los lugares que había visto en una película de Wim Wenders, The State of Things (1982), donde la trama es el rodaje de una película que nunca llega 

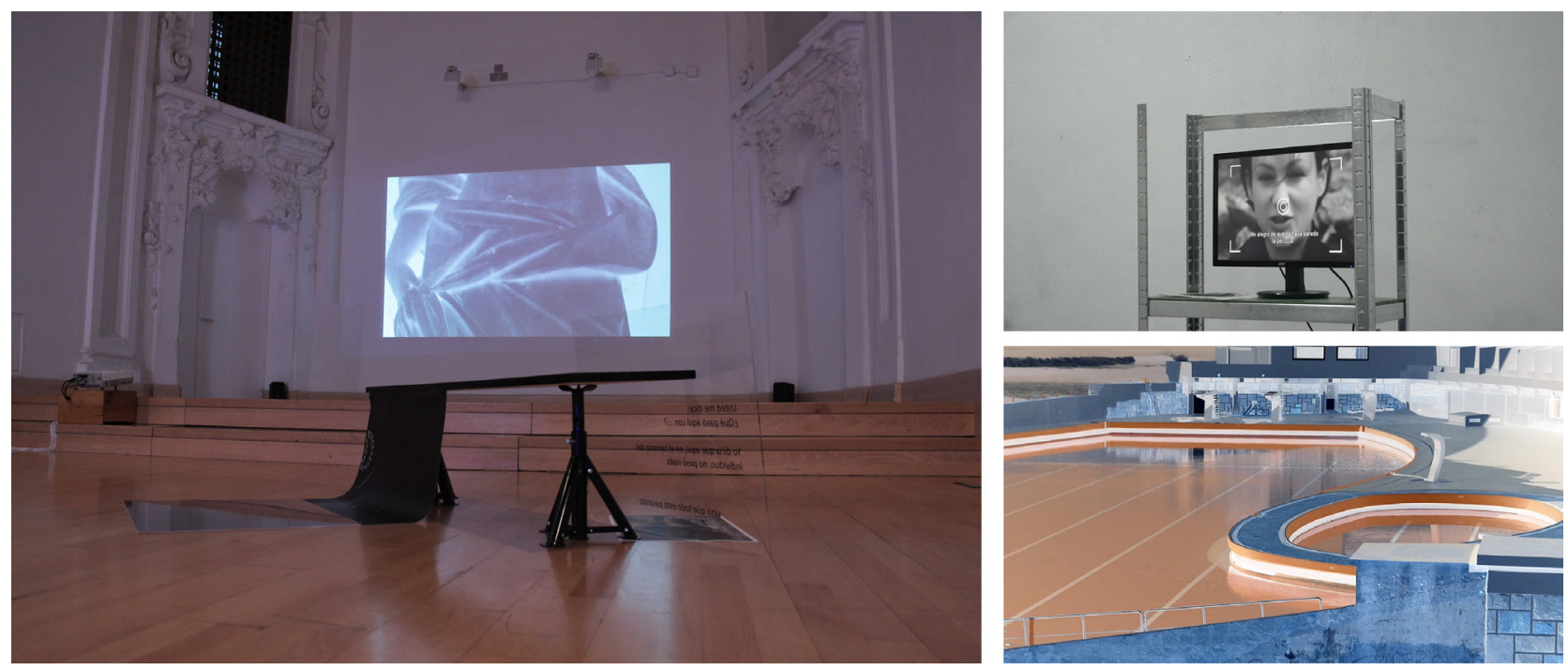

3.1. Vista de Abel Jaramillo, Sin título (2019) y The need to have walls (2019) y 3.2. Capturas de The need to have walls

a sucederse. Todo el viaje es una cadena de desventuras (la cámara que Abel compró en un mercadillo no funcionaba, el autobús no le llevó a donde deseaba) y un entregarse al devenir. Tras vagar por un tiempo recreó las imágenes de ese lugar que había idealizado: «Puede que lo que le llevó a estar frente al mar fuera saber que había ido para nada. Para no terminar nada, solamente para seguir. Para filmar algunas escenas en los mismos lugares que aquella película le obsesionaba», narra el texto que el artista elaboró para el vídeo [3.1] y [3.2].

\section{¿Y ahora?}

En tiempos de fluidez, discontinuidad y fragmentación, el continuum de imágenes y cuerpos al que nos sometemos diariamente, como diría Debord, anega el tiempo de recogimiento necesario para la producción de nuestra subjetividad. La idea de Seguir, seguir, hacer lo siguiente es el imperativo de nuestro tiempo para no abocarnos al ostracismo pues estamos condenados al contacto. Esta exposición señala puntos de fuga de ese estar juntos que nos hagan más conscientes de nuestro lugar en el mundo. Escribe Clàudia Elies en el texto de la publicación editada junto a la muestra: «Bajar a mi barrio mientras escribo estas líneas y ver que el vecino sobrevive al turismo, el panadero sobrevive gracias al turismo, el turista sobrevive al trabajo viniendo de vacaciones, la señora mayor sobrevive como puede a su renta antigua acechada por el turista».

José Luis Panea

Universidad de Castilla-La Mancha 